\title{
Determinants of Profitability in Banking Sector: An Evidence from Pakistan
}

\author{
Hasan Raza, Assistant Professor \\ Atiya Saeed, M.Phil. Scholar \\ Samreen Hena, M.Phil. Scholar
}

Department of Commerce, University of Karachi, Karachi, Pakistan

URL:http://dx.doi.org/10.19044/esj.2019.v15n7p35

\begin{abstract}
This research explores the association of bank specific characteristics and its profitability. Profitability of bank relates to external and internal factors i.e. size, capital, loan and deposit generally. The study is mainly concerned with the internal factors which have an effect on the profitability of the banks in Pakistan. 34 Banks including 21 Local Private Banks, 9 Public Sector Commercial Banks, 4 Foreign Banks and 4 Specialized Banks operate their services in Pakistan. Data has been taken of overall banking industry from the website of the Central Bank, the State Bank Pakistan (SBP) for the period 2006-2016. Ordinary Least Square (OLS) method has been used with the help of E-View statistical software. Spread Ratio (SR) and Net Interest Margin (NIM) are considered for indicators of profitability (Dependent Variables) whereas Size, Capital, Loan and Deposit are used as explanatory variables. The result reveals that size of asset has negative and significant effects on profitability, the banks loans has positive impact on bank performance, capital associates positively with NIM but shows adverse effects on SR and Deposit does not exhibit any prominent influence on profitability of banks in Pakistan.
\end{abstract}

Keywords: Banks, Profitability, Spread Ratio, Net Interest Margin, Ordinary Least Square (OLS), Pakistan.

\section{INTRODUCTION:}

Economic growth and stability of any country is widely depending on the financial sector strength. Banking industry is one of the main part of financial sector, and for permanent and continuous economic growth banking sector of any country must be comprehensive and well-performing. Banking sector support economy's other sectors in several manners such as turning into financing source, providing payments settlement facility and play an important part in trade of any product. Pakistani banking sector consist of local, foreign 
Islamic specialized and public-sector banks. Covering the period of 69 years banking sector Pakistan has perceived serious changes in terms of growth and development. After the independence, banking sector of Pakistan had to face deficiency of capital and ambiguity due to political and various other reasons. For the expansion and growth of financial sector on 1st July 1948, central Bank the "State bank of Pakistan (SBP) " was established. Subsequently, SBP ACT 1956 regulatory and numerous adjustments were made for the growth and stability of banking industry. In 1974, nationalization of all private banks further debilitate the performance of banking sector because of deprived quality of services and products of banks. In the 1990s decade, some banks were privatized under the reform policy of banking sector. According to SBP currently 34 scheduled banks operating all over Pakistan by the end of December 2016 and out of these only 9 banks are owned by public sector with 2975 branches, 21 local private banks with 10,008 branches, 4 foreign banks with 10 total numbers of branches and 4 Specialized banks having 628 branches.

Over the past few years the tendency of Pakistan banking sector was in the direction of establishment and enhancement of Islamic banking, privatization, competition, deregulation and mergers. Because of these alternations, competition possibility has increased and enhances the consumer's choices. Such considerable changes in structure and significant increase in competition, the banking sector of Pakistan had been continued under exploration to bring innovation, improvement in service and enhanced quality of product. The current study uses time series data to study Pakistan banks profitability. Majority of the research concluded that internal factors interpret an immense percentage on profitability of bank along with other external factors, although, these relations are not identical universally. Therefore, resolving this dispute and to examine relationship further research are required.

\section{Current position:}

The banking sector had its balance sheet size increased during CY16. In CY16, banking sector's total assets jumped to Rs. 15.98 trillion, up 12.02\% from previous year's Rs. 14.27 trillion. Percentage increases in total liabilities and equities were $12.51 \%$ and $7.19 \%$ respectively for the year CY16. The banking sector's expansion mainly comes from the balance sheet size growth of the local banks, which registered a rise of $11.32 \%$. Foreign banks, which represent $2.45 \%$ share of the banking sector, registered a growth of $9.73 \%$ in CY16. In CY16, banking sector's profit before and after tax found declines of Rs.7.59 billion or $2.32 \%$ and Rs.1.97 billion or $1.01 \%$ respectively compared to CY15. On the whole, however, the banking sector of Pakistan showed tremendous trends of growth in the past financial years. The statistics quoted 
here come from Pakistan Statistical Bulletin published by State Bank of Pakistan.

\section{Problem statement}

The main purpose of any business is to maintaining profitability and banks are also included in them. Profit is an imperative element for the proper and even performance of any business in the existing aggressive surrounding and the performance of the firms is affected by it notably, as the budgetary potential of banks can in addition force the financial advancement. While identifying bank profit determinant, there is a chance to evaluate which variable have more impact on profit, and it is very important for management to make timely decisions. Over the past 30 years the greater part of the research allocates substantial time and cash in the significance of the commercial variable and different studies and investigations have made to link different factors. This study diverts the attention to the importance of factors that we will lead think about and to direct an investigation about the banks determinants of the profitability which is essential for the owner as well as for the management and decision makers to take timely action which improve banks efficiency and profit. (Tariq , Usman, Mir, \& Aman, 2014)

\section{Objective of study}

The aim of current study is to make realize the impact of bank internal factors on profitability in Pakistan. Secondary data of all Pakistani scheduled banks currently operating from 2006-2017 is being used in this study. Scheduled banks have three main groups' i.e. foreign banks, public-sector banks, and domestic private banks in Pakistan. Public sector commercial banks and specialized banks are the further division of public sector banks. We used time series data and regression analysis to discover the association between the main internal factors and profitability of 34 Pakistani banks.

The research on profitability variables of banks is significant for organizations directors, sponsors and government, as they can analyze the efficiency of banks and retain the depositor's choices, matching government plans and management policies to attain the future target. (Mamatzakis \& Remoundos , 2003)

\section{Study Limitations}

$>$ The research is principally based on secondary data extracted from annual financial statements of banks.

$>$ Factors utilized as a part of this study in light of past research and restricted to previous research in Pakistan. 
$>$ Only limited internal factors are used in this study. Some of the other factors (internal /external) which are likely to impact the performance of banks are ignored in this study.

\section{LITRETURE REVIEW}

Past literature associate with this study is discussed in this section. There is a wide-ranging literature which follows distinguishing the factors of banks profitability. Profitability determinant may be grouped into two fractions; internal and the external. The internal factors can be affected by the objective policies and decisions of management. Bank operating result that contains profitability is induced by mission, regulations and actions that taken through management (Staikouras \& Wood, 2011). Current study specifies (Spread Ratio) SR and (Net Interest Margin) NIM as dependent variable and Size (logarithm of Total Assets), Deposit(D), Loan(L) and Capital(C) as independent variable.

Bhatia, Mahajan, and Chander (2012) worked on 23 Indian banks profitability determinants. They explore that Profit to per employee ratio, Business to per employee ratio, Capital adequacy ratio and Noninterest income ratio shows a direct relation with ROA which use as a profitability, although, the ratio between investment and deposit show a negative relationship with ROA. (Bhatia, Mahajan, \& Chander, 2012)

Staikouras and Wood (2011) European Bank Profitability and took the sample size of 547 small banks and 138 large banks making a total of 685 European banks. The results recommend that the European banks profitability does not only influence by internal factors but also observe effects of changes in the macroeconomic or external factors. Significance with equity ratio means that the bank with higher equity has higher profitability. (Staikouras \& Wood, 2011)

Kamran, Johnson and Sammer (2016) worked on external and internal factors impacts on banks profitability for the period of 2005-2009 by selecting 44 banks of Pakistan. The study specifies Spread Ratios (SR) as the dependent variable, the result concluded that the Size, Leverage Ratio and GDP have significant influence on profitability of Pakistani banks while as Loan, Inflation, Growth of Deposit and MC have insignificant impact on bank profitability. ( Kamran, Johnson, \& Sammer, 2016).

Ali, Akhtar, Ahmed (2011) examined the profitability indicator of Public and Private Commercial Banks for the time period during 2006-2009. ROE and ROA used as a profitability measures. The result concluded that ROA has positive impact on Operating efficiency, Assets Management, Portfolio Composition, Size and negatively associated with Credit Risk and Capital while as ROE has positive relation with, Portfolio Composition, Capital and Assets Management and indirectly relates to Operating efficiency, 
Size and Credit Risk. GDP found positive relation with both ROE and ROA. (Ali , Akhtar, \& Ahmed, 2011 )

Kristianti and Yovin(2016) worked on the top 10 government and private banks of Indonesia for the period 2004-2013 wherein ROA is used as a profitability measure. They examine two-different model one for government banks and other for private banks. The finding suggests that for the government banks Operational Efficiency, NIM, and NPL are the significant factor and for the private sector Capital Adequacy Ratio (CAR) and Operational Efficiency are significant. (Kristianti \& Yovin , 2016).

Management should extensively give attention for liquidity and credit transactions explored by Ameer (2015). She examines the banks specific and macroeconomic factors impact on profitability. She founds that higher the loan to assets ratio revels higher profitability. The result also indicates the positive insignificant relationship with GDP. FDIs also have positive impact on the bank performance as well as economic growth of country. This study deals with the internal and external indicators impact on individual Pakistan banks profitability for the period of 2010-2014 (Ameer , 2015).

A profitable and strong banking industry has more ability to face adverse shocks and take active part in economy stability by Aljbiri. This study used panel data from 2000-2010 to examine the factors affecting the performance and profitability of Gumhouria banks in the country of Libya. The results show that Capital Adequacy, Portfolio Composition, Deposits, and GDP affect the ROE while other variables, such as Inflation and Size of bank also have significant but weak influence on the profitability (Aljbiri, 2013).

The negative impact of bad quality of loan on Albanian banks is very problematic issues explore by Duraj and Moci. The study explores the impact of internal as well as external factor affecting 17 Albanian banks profitability. The finding suggests that Deposit to Loan ratio and GDP have significantly positive impact on ROE. The other factors like Total Loan and Inflation has significantly negative relation with ROE. While as NPL are insignificant. (Duraj \& Moci, 2015)

High amount of Capital has a tendency to create high Net Interest Margin (NIM) and profitability concluded by Naceur. He explored the impact of bank’s financial structure, banks' characteristics macroeconomic indicators on net interest margins and profitability in the banking industry of Tunisia for the period covering 1980-2000. The result shows that stock market development and bank loans have a significant positive relation with NIM. Size found to have negative impact on Tunisian banks profitability while banking profitability has not been affected by GDP and Inflation. (Naceur, 2003)

Alpera and Anbarb evaluate the bank internal and external determinant of the 10 Turkish banks profitability over the period of 2002-2010. ROA and 
ROE is used as a profitability indicator. They find that non-interest income and size and /assets ratio has a direct relation with return on assets. Loan has a negative impact that shows a credit portfolio and bad assets quality has adverse impact on the return on assets. (Alpera \& Anbarb, 2011).

Ćurak, Poposki and Pepur (2012) analyzes bank-specific, industryspecific and macroeconomic determinants of bank profitability by taking 16 Macedonian banks as a sample for the period during 2005 and 2010. According to them, operating expense management is the most imperative bank internal factors for profitability determinant. However, liquidity risk and solvency risk are also influenced profitability. While as in Macedonia economy external variable, banking system reform concentration and growth of economy shows considerable impact on profitability of bank. (Ćurak, Poposki, \& Pepur, 2012)

Athanasoglu, Delis and Staikouras (2006) found statistically insignificant relation between size and profitability. Size generally explains economies of scale in the market. Banks larger in size have more ability to avail economies of scale benefits which eventually cause profit increase. (Athanasoglou, Delis, \& Staikouras, 2006)

Manoj (2010) research on Kerela state (KOPBs) old private sector banks. The dependent variable was Operating profit ratio (OPR) while the independent variable was Net Interest Margins used as a proxy of operational efficiency. Other variables include non-interest income, investment in government securities, assets and ratio of rural branches to semi urban and metropolitan branches. The outcomes indicate a positive and significant connection amongst non-interest income and OPR however; there was a firm negative relationship between investment in government securities and net interest margin. (Manoj, 2010)

Capraru and Ihnatov (2014) evaluate the core determinants of banks' profitability in five chosen Central and Eastern European states for the span of 2004 to 2011. 143 commercial banks from Bulgaria Poland, Hungary, Czech Republic and Romania were taken as sample for study. They use proxy the Return on Average Assets (ROAA), the Return on Average Equity (ROAE) and net interest margin (NIM) for banks profitability. They found the direct relationship between profitability and management efficiency as well as capital adequacy. Banks with higher capital adequacy produce higher profits; However, Size shows a negative effect on NIM. (Căpraru \& Ihnatov , 2014)

\section{METHODS AND RESOURCES}

The study engaged in to find out the Pakistani banks profitability determinant covering the period of 2006-2016. State Bank of Pakistan Statistical Bulletin is the primary source of data analyzed in this study. We use time series data from 2006 to 2016. For analyzing and data management 
purpose we use liner regression and E-Views and to obtain relationship and finding significance level between performance indicators regression analysis is used.

To calculate mean, median and standard deviation descriptive statistics is used.

Profitability equation:

$\mathrm{Y}=\beta_{0}+\beta_{1} X_{1}+\beta_{2} X_{2}+\beta_{3} X_{3}+\beta_{4} X_{4}+€$,

Where:

Y represents Spread Ratio and Net Interest Margin for bank i at time $t$

$\mathrm{X}_{1}$ represent Size of bank i at time $\mathrm{t}$

$\mathrm{X}_{2}$ represent Deposits of bank $\mathrm{i}$ at time $\mathrm{t}$

$\mathrm{X}_{3}$ represent Loan of bank $\mathrm{i}$ at time $\mathrm{t}$

$\mathrm{X}_{4}$ represent Capital of bank $\mathrm{i}$ at time $\mathrm{t}$

$€$..........Error term.

The above equation of profitability shows the relationship of profitability indicator (SR and NIM) with bank internal factors (Deposits (D), Size (S), Loan (L) and Capital (C)) The $\beta_{1}, \beta_{2}, \beta_{3}$ and $\beta_{4}$ which called Beta value represents the proportional change in dependent variable because of independent variables. Constant $\beta_{0}$ shows the of $x$-intercept value and $€$ shows error term.

\section{Selected Variables \\ Dependent Variables \\ Spread Ratio:}

It is the amount of Net Markup divided by Interest Income. The reduction of the spreads is one of the expected benefits of financial liberalization and expanding of the financial sector. This is established on the understanding that liberalization improves competition and productivity in the financial sector.(Were \& Wambua, 2014)

\section{Net Interest Margin}

This ratio directs the earning capacity by employ all assets. Normally, banks use funds of savers (deposits) to advance loans. NIM is the ratio between the difference of bank's interest income and interest expense to total assets. NIM is similar to the non-financial businesses gross margin. it is mainly focused on the profit earned on interest activities. (Gul, Irshad, \& Zaman, 2011) 


\section{Independent Variables}

Size

As per previous studies, total assets of banks (natural logarithm) are term as the proxy of size of bank. Size usually has a positive impact on profitability. (Khan, Ijaz, \& Aslam, 2014)

\section{Deposit}

The ratio shows what portion of total deposit encompasses total assets.

\section{Loan}

Better capitalized banks appear to be more profitable and successful. Research found that loan volume of banks is increasing quickly than the market and influence profitability of bank in a favorable way. Previous literature shows both negative and positive relation between the bank liquidity and profitability. ( Ameer , 2015)

\section{Capital}

The ratio shows percentage of total equity comprises in total assets.

Table 1: Selected Variable and Proxies

\begin{tabular}{|l|l|l|}
\hline Sr No & Proxies & Formula of Ratios \\
\hline \multicolumn{2}{|l|}{ DEPENDENT VARIABLES } \\
\hline 1 & Spread Ratio (SR) & $($ Net Markup/ Interest Income)/ (Markup/ Interest Income) $* 100$ \\
\hline 2 & Net Interest Margin (NIM) & (Total Interest Income- Total Interest Expense)/Total Assets * 100 \\
\hline INDEPENDENT VARIABLES & \multicolumn{2}{|l|}{} \\
\hline 3 & Size (S) & Natural Logarithm of Total Assets \\
\hline 4 & Deposit (D) & Total Deposit/ Total Assets * 100 \\
\hline 5 & Loan (L) & Total Liabilities/ Total Assets * 100 \\
\hline 6 & Capital (C) & Total Equities/ Total Assets * 100 \\
\hline
\end{tabular}

Hypothesis Development:

The motive of current study is observing the impact of internal factors on profitability of banks in Pakistan. Following the objective, the current study tries to test the following hypothesis:

H1: There is no significant effect of SIZE on SR.

H2: There is no significant effect of the DEPOSIT on SR.

H3: There is no significant effect of the LOAN on SR.

H4: There is no significant effect of the CAPITAL on SR

H5: There is no significant effect of SIZE on NIM.

H2: There is no significant effect of the DEPOSIT on NIM.

H3: There is no significant effect of the LOAN on NIM.

H4: There is no significant effect of the CAPITAL on NIM. 


\section{ECONOMETRIC RESULT AND DISCUSSION:}

This particular section explains the results of the study consist of econometric results and descriptive statistics of the model. The empirical evidence on the banks profitability determinant or Spread Ratio (SR) and Net Interest Margin (NIM) is based on time series data.

Table: 2 shows Pakistani banks average performance in respect of internal factors influencing the profitability between 2006 and 2016 and reported the mean scores. The mean value of SR was 5.03\%, NIM was $0.038 \%$, deposits, was $7.04 \%$, Loan was $9.08 \%$ and Bank Size which measure by Logarithm of Total assets $22.8 \%$, and Capital which is proxy of the equity ratio was $0.78 \%$.of Pakistani banks from 2006 to 2016.

Table 2: Descriptive Statistics

\begin{tabular}{|l|l|l|l|l|l|l|}
\hline & SR & NIM & LOG(SIZE) & DEPOSIT & LOAN & CAPTAL \\
\hline Mean & 5.038200 & 0.037282 & 22.84782 & 7.405427 & 9.082718 & 0.788336 \\
\hline Median & 0.465100 & 0.038700 & 22.83954 & 0.749000 & 0.902900 & 0.084300 \\
\hline Maximum & 50.63000 & 0.041800 & 23.49490 & 73.90000 & 90.88000 & 7.830000 \\
\hline Minimum & 0.429400 & 0.030500 & 22.16161 & 0.734700 & 0.894700 & 0.075300 \\
\hline Std. Dev. & 15.12115 & 0.004150 & 0.433168 & 22.05376 & 27.12909 & 2.335461 \\
\hline Skewness & 2.846009 & -0.367246 & -0.024942 & 2.846047 & 2.846050 & 2.846024 \\
\hline Kurtosis & 9.099863 & 1.627055 & 1.826249 & 9.099992 & 9.099999 & 9.099912 \\
\hline & & & & & & \\
\hline Jarque-Bera & 31.90339 & 1.111209 & 0.632582 & 31.90451 & 31.90458 & 31.90382 \\
\hline Probability & 0.000000 & 0.573725 & 0.728847 & 0.000000 & 0.000000 & 0.000000 \\
\hline & & & & & & \\
\hline Sum & 55.42020 & 0.410100 & 251.3261 & 81.45970 & 99.90990 & 8.671700 \\
\hline Sum Sq. Dev. & 2286.491 & 0.000172 & 1.876349 & 4863.683 & 7359.875 & 54.54380 \\
\hline & & & & & & \\
\hline Observations & 11 & 11 & 11 & 11 & 11 & 11 \\
\hline
\end{tabular}

\section{Regression Analysis:}

Table 3: Impact of Internal Factors on SR

Dependent Variable: SR

Method: Least Squares

Included observations: 11

\begin{tabular}{lllll}
\hline \hline Variable & Coefficient & Std. Error & t-Statistic & Prob. \\
\hline \hline C & 1.690946 & 0.614398 & 2.752199 & 0.0332 \\
LOG(SIZE) & -0.073184 & 0.026927 & -2.717830 & 0.0347 \\
DEPOSIT & -0.848349 & 0.652624 & -1.299905 & 0.2413 \\
LOAN & 1.633761 & 0.524292 & 3.116127 & 0.0207 \\
CAPTAL & -4.486974 & 1.874897 & -2.393184 & 0.0538 \\
\hline \hline R-squared & 0.999998 & \multicolumn{2}{c}{ Mean dependent var } & 5.038200
\end{tabular}




\begin{tabular}{llll} 
Adjusted R-squared & 0.999996 & S.D. dependent var & 15.12115 \\
S.E. of regression & 0.029228 & Akaike info criterion & -3.924410 \\
Sum squared resid & 0.005126 & Schwarz criterion & -3.743548 \\
Log likelihood & 26.58425 & Hannan-Quinn criter. & -4.038418 \\
F-statistic & 669120.3 & Durbin-Watson stat & 2.305885 \\
Prob(F-statistic) & 0.000000 & & \\
\hline
\end{tabular}

\section{Table 4: Impact of Internal Factors on NIM}

Dependent Variable NIM

Method: Least Squares

Included observations: 11

\begin{tabular}{lllll}
\hline \hline Variable & Coefficient & Std. Error & t-Statistic & Prob. \\
\hline \hline C & 0.176547 & 0.039257 & 4.497254 & 0.0041 \\
LOG(SIZE) & -0.006171 & 0.001721 & -3.586600 & 0.0116 \\
DEPOSIT & -0.030194 & 0.041699 & -0.724095 & 0.4963 \\
LOAN & -0.006464 & 0.033499 & -0.192948 & 0.8534 \\
CAPTAL & 0.360293 & 0.119796 & 3.007560 & 0.0238 \\
\hline \hline R-squared & 0.878477 & Mean dependent var & 0.037282 \\
Adjusted R-squared & 0.797462 & S.D. dependent var & 0.004150 \\
S.E. of regression & 0.001868 & Akaike info criterion & -9.425454 \\
Sum squared resid & $2.09 E-05$ & Schwarz criterion & -9.244592 \\
Log likelihood & 56.84000 & Hannan-Quinn criter. & -9.539462 \\
F-statistic & 10.84334 & Durbin-Watson stat & 2.129270 \\
Prob(F-statistic) & 0.006524 & &
\end{tabular}

Table 3: Spread Ratio

Table 3 represented the econometric result. The model shows Rsquared value 0.99 which explain that $99 \%$ of the variation in the dependent variable is explained by the independent variables of the model (SR), only $1 \%$ variation in the dependent variable remains unexplained by the independent variables of the study. The F-statistic value 0.00 indicates significant endorsing the soundness and stability of the current model relevant. Secondly the D.W. statistic was about 2.305 implying that there was evidence of correlation in the data.

$>$ Our independent variable Size, which is measured by Logarithm of Total assets has Probability 3.4\% which is less than 5\%. Result of Coefficient shows a significant indirect relationship among SR and SIZE. This means SIZE have a significant negative impact on Spread Ratio. This result gives provision to the recent studies that mention the diseconomies of scale that happen from a level of size increase. Growing banks may face diminishing marginal returns so average profits would weaken with SIZE. (Staikouras \& Wood, 2011) 
$>$ DEPOSIT shows $24.13 \%$ probability value which is greater than $5 \%$. The result concludes that there is an insignificant relationship between SR and DEPOSIT. It is true that deposit is one of the major and important source of banks direct earning but too much based on them cause a negative impact on profitability

$>$ LOAN shows positive relation with $2.07 \%$ probability which is less than 5\%. Banks earn higher amount of interest through lending long and short-term loans. It is the main source of bank earning. The result explains that LOAN has positive impact on banks profitability which means greater the bank lending greater will be the profit in form of interest income.

> CAPITAL with Probability value $5.38 \%$ show direct and negative significant relation with SR.

Table 4: Net-Interest Margin:

Table 4 represented the model shows R-squared value 0.87 which explain that $87 \%$ of the variation in the dependent variable is explained by the independent variables of the model (NIM). F-statistic with 0.006 shows that model is statistical significance. All variables show negative relationship except CAPITAL

$>$ SIZE with higher significance level shows indirect association with NIM, explaining the fact that the higher the size of banks the lower margin of profit because of the economies of scale. (Căpraru \& Ihnatov , 2014)

$>$ DEPOSIT with $49.63 \%$ Probability value which is more than $5 \%$ indicates negative relationship with NIM. Higher deposit may increase the risk and negative impact on the investment capacity of banks.

$>$ LOAN with $85 \%$ Probability value shows an indirect relation with NIM. While as CAPITAL with 2.3\% Probability shows a significant positive relation with NIM. Banks by utilizing their capital and assets by investment in different economy sectors generate a higher interest earning with low financial cost and that ultimately result in increase in profit.

\section{CONCLUSION:}

Profitability is a significant measure of the performance of banks especially in the varying condition of banking industry. This research inspects the determinants of banks profitability in Pakistan. For the purpose, time series data and regression analysis is applied to data which is obtained from State Bank of Pakistan from 2006 to 2016. We find that asset size has a negatively and significant effect on profitability. It suggests that larger banks may face diminishing marginal returns so average profits would decline as size 
increased. Bank loans are expected to be the key source of income and are expected to have a positive relation on bank performance. As expected we found a positive relationship between profitability and loans. Another bankspecific variable, CAPITAL which is proxy of equity ratio has a positive and significant effect on NIM but show negative relation with SR. The remaining bank-specific factor DEPOSIT has not important effect on bank profitability.

\section{FUTURE DIRECTION OF THE RESEARCH}

The study has been done on Pakistani banking sector using the data (consolidated financial reports) of the past 11 years however, some other points that define direction of future the research are:

- The study has been done using an exact definition of profits i.e. Profit After Tax to Total Income. However, profits can be defined in some other way also that may change the results. Also, the study has been done using some certain independent variables. There could be some more factors that can be observed into in a different perspective.

- The other direction for further study is that it can be conducted considering a different economic environment other than the Pakistan economy. In that case, a global study considering different limitations and parameters.

- Some qualitative factors such as service quality, customer relations, and satisfaction of the employees may be measured in a separate study. A complete study that considers both qualitative and quantitative factors may also be taken up.

\section{References:}

1. Ameer , B. M. (2015). Determinants of Banking Sector Performance in Pakistan . Global Journal of Management and Business Research: C Finance Volume 15 Issue 6 Version 1.0, pp 21-48.

2. Ali , K., Akhtar, M. F., \& Ahmed , P. Z. ( 2011 ). Bank-Specific and Macroeconomic Indicators of Profitability - Empirical Evidence from the Commercial Banks of Pakistan. International Journal of Business and Social Science, Vol. 2 No. 6, pp235-242.

3. Aljbiri, A. (2013). FACTFactors Affecting Gumhouria Bank's Profitability. Empirical Evidence From Biggest Commercial Bank In Libya. ACTA UNIVERSITATIS AGRICULTURAE ET SILVICULTURAE MENDELIANAE BRUNENSIS,Vol LXI No. 7, pp 1941- 1949.

4. Alpera, D., \& Anbarb, A. (2011). Bank Specific and Macroeconomic Determinants of Commercial Bank Profitability: Empirical Evidence 
from Turkey. Business and Economics Research Journal, Vol 2 ,No. 2 , ISSN: 1309-2448, pp. 139-152.

5. Athanasoglou, P. P., Delis, M. D., \& Staikouras, C. K. (2006). Determinant of Bank Profitability In The South Eastern European Region. Munich Personal RePEc Archive, Paper No 10274.

6. Bhatia, A., Mahajan, P., \& Chander, S. (2012). Determinants of Profitability of Private. Journal of Commerce and Accounting Research, Vol 1 Issue 2, pp 14-22.

7. Căpraru, B., \& Ihnatov , I. (2014). Banks' Profitability in Selected Central and Eastern European Countries . Procedia Economics and Finance, Vol16, pp 587 - 59.

8. Ćurak, M., Poposki, K., \& Pepur, S. (2012). Profitability Determinants of the Macedonian Banking Sector in Changing Environment. Procedia - Social and Behavioral Sciences, Vol 44, pp 406 - 416.

9. Duraj, B., \& Moci, E. (2015). Factors Influencing The Bank Profitability - Empirical Evidence From Albania. Asian Economic and Financial Review, 5(3), pp 483-494.

10. Gul, S., Irshad, F., \& Zaman, K. ( 2011). Factors Affecting Bank Profitability in Pakistan . The Romanian Economic Journal, Vol XIV, no. 39 , pp 61-87.

11. Khan, M. M., Ijaz, F., \& Aslam, E. (2014). Determinants of Profitability of Islamic Banking Industry: An Evidence from Pakistan. Business \& Economic Review: Vol. 6, Issue 2, pp. 27-46.

12. Kristianti, R. A., \& Yovin . (2016). Factors Affecting Bank Performance: Cases of Top 10 Biggest Government and Private Banks in Indonesia in 2004 - 2013. Review of Integrative Business and Economics Research, Vol 5(4), pp 371-378.

13. Kamran, H. W., Johnson, Z., \& Sammer, M. (2016). Determinants Of Profitability In Banking Sector. International Journal of Information Research and Review Vol. 03, Issue, 05, pp. 2258-2264.

14. Mamatzakis, E. C., \& Remoundos , P. C. (2003). Determinant Of Greek Commercial Banks Profitability, 1989 - 2000. SPOUDAI», Vol. 53, No 1, 84-94.

15. Manoj. (2010). Determinants of Profitability and Efficiency of Old Private Sector Banks in India with Focus on Banks in Kerala State: An Econometric Study. International Research Journal of Finance and Economics ISSN 1450-2887 Issue 47, pp 7-21.

16. Naceur, S. B. (2003). The Determinants Of The Tunisian Banking Industry Profitability: Panel Evidence. ERF Research Fellow.

17. Staikouras, C. K., \& Wood, G. E. (2011). The Determinants Of European Bank Profitability. International Business \& Economics Research Journal Vol 3, Number 6, PP 57-68. 
18. Tariq, W., Usman, M., Mir, H. Z., \& Aman, I. (2014). Determinants of Commercial Banks Profitability: Empirical Evidence from Pakistan. International Journal of Accounting and Financial Reporting ISSN 2162-3082 Vol. 4, No. 2, pp 1-22.

19. Were, M., \& Wambua, J. (2014). What factors drive interest rate spread of commercial banks? Empirical. Review of Development Finance Vol 4, pp 73-82. 